\title{
In vitro and in vivo antileishmanial activity of Artemisia annua L. leaf powder and its potential usefulness in the treatment of uncomplicated cutaneous leishmaniasis in humans
}

\author{
Luz Estella Mesa ${ }^{[1]}$, Daniel Vasquez ${ }^{[1]}$, Pierre Lutgen ${ }^{[2]}$, Iván Darío Vélez $^{[1]}$, \\ Adriana María Restrepo ${ }^{[1]}$, Isabel Ortiz ${ }^{[3]}$ and Sara María Robledo ${ }^{[1]}$
}

[1]. Programa de Estudio y Control de Enfermedades Tropicales-PECET, Instituto de Investigaciones Médicas, Facultad de Medicina, Universidad de Antioquia, Medellín, Colombia. [2]. Iwerliewen Fir Bedreete Volleker-IFBV- Réseau belgo-luxembourgeois de valorisation des herbes médicinales-BELHERB, Niederanven, Luxembourg. [3]. Grupo de Investigación Biología de Sistemas, Universidad Pontificia Bolivariana. Medellín, Colombia.

\begin{abstract}
Introduction: Cutaneous leishmaniasis (CL) is a tropical disease that affects millions of individuals worldwide. The current drugs for CL may be effective but have serious side effects; hence, alternatives are urgently needed. Although plant-derived materials are used for the treatment of various diseases in $80 \%$ of the global population, the validation of these products is essential. Gelatin capsules containing dried Artemisia апnиа L. leaf powder were recently developed as a new herbal formulation (totum) for the oral treatment of malaria and other parasitic diseases. Here, we aimed to determine the usefulness of $A$. annua gel capsules in CL. Methods: The antileishmanial activity and cytotoxicity of $A$. апnиa L. capsules was determined via in vitro and in vivo studies. Moreover, a preliminary evaluation of its therapeutic potential as antileishmanial treatment in humans was conducted in 2 patients with uncomplicated CL. Results: Artemisia annua L. capsules showed moderate in vitro activity in amastigotes of Leishmania (Viannia) panamensis; no cytotoxicity in U-937 macrophages or genotoxicity in human lymphocytes was observed. Five of $6(83.3 \%)$ hamsters treated with $A$. аппиа capsules $(500 \mathrm{mg} / \mathrm{kg} /$ day $)$ for 30 days were cured, and the 2 examined patients were cured 45 days after initiation of treatment with $30 \mathrm{~g}$ of $A$. апnиa $\mathrm{L}$. capsules, without any adverse reactions. Both patients remained disease-free 26 and 24 months after treatment completion. Conclusion: Capsules of $A$. аппиа L. represent an effective treatment for uncomplicated CL, although further randomized controlled trials are needed to validate its efficacy and safety.
\end{abstract}

Keywords: Cutaneous leishmaniasis. Artemisia annua. Leishmania panamensis. Anti-leishmanial activity.

Therapeutic response.

\section{INTRODUCTION}

Leishmaniasis is a tropical disease that is caused by $>20$ species of Leishmania, an intracellular protozoa transmitted by sandflies of the Phlebotomus and Lutzomyia spp. The disease is clinically manifested as cutaneous leishmaniasis (CL), mucosal leishmaniasis (ML), and visceral leishmaniasis (VL); these clinical forms differ in terms of immunopathology and the degree of morbidity and mortality ${ }^{1}$. The disease is endemic in 98 countries in 5 continents, primarily including poorly developed or developing nations. The World Health Organization (WHO) estimates that approximately 12 million individuals are affected and 350 million people are at risk o infection. CL is the most prevalent clinical manifestation with 0.7-1.2 million new cases per year, whereas

Corresponding author: Dra Sara M. Robledo.

e-mail: sara.robledo@udea.edu.co

Received 31 October 2016

Accepted 17 January 2017
VL affects 0.2-0.4 million individuals; however, the number of such cases in endemic areas is known to be underreported ${ }^{2}$. The standard treatment for CL includes a pentavalent antimonial [meglumine antimoniate (MA) or sodium stibogluconate], miltefosine, pentamidine isethionate, or amphotericin B. Although these drugs are still effective, they have serious side effects ${ }^{3}$; hence, there is an urgent need for research and development to produce safer and effective, but also inexpensive drugs.

Plants represent a natural source of medications to treat human diseases, and thousands of potent biological metabolites have been identified thus far from plants. Moreover, several such metabolites have been used to discover and develop drugs or have been used as scaffolds for designing better pharmacologically active compounds 4 . Approximately $80 \%$ of the global population use phytomedicine for treating infectious and non-infectious diseases; hence, herbal medicine has received marked scientific interest, particularly for the validation of the medicinal use of plants. In fact, the World Health Organization 
recently updated the Traditional Medicine Strategy for 2014-2023 to prioritize traditional and complementary medicine products 5 .

An overwhelming number of scientific reports have focused on compounds from plants with validated, both in vitro and in vivo, antileishmanial activity; however, very few plant products have advanced to the clinical phase of evaluation in humans. Artemisia annua L. (Asteraceae), commonly named as sweet wormwood or Qing Hao, is one such plant. It is a Chinese medicinal plant traditionally used for the treatment of fever and chills, as well as malaria ${ }^{6,7}$. The main metabolites present in this plant, including artemisinin, coumarins, flavonoids, saponins, and terpenoids, have demonstrated a wide range of pharmacological activities against metabolic diseases such as cancer ${ }^{8}$ and diabetes 9 , as well as infectious agents such as viruses $^{10,11}$ and Trypanosoma and Leishmania protozoa ${ }^{12-16}$.

Pulverized entire leaves of $A$. аппиа L. (80\% leaves and $20 \%$ thin branches), known as totum, seem to represent a novel botanical drug for the treatment of infectious diseases, including malaria, with good results and without side effects ${ }^{17}$. The phytochemical analysis of this $A$. апnи $\mathrm{L}$. powder indicated the presence of $0.1 \%$ artemisinin, $0.1 \%$ scopoletin, $0.2 \%$ alphapinene, $0.5 \%$ limonene, $0.6 \%$ eucalyptol, $1.6 \%$ artemisia ketone, $0.2 \%$ camphor, $0.8 \%$ caryophyllene, and $0.8 \%$ polyphenols (Laboratoire National de Sante, 3583 Dudelange, Luxemburg). Moreover, an unexpectedly high level of transfer of artemisinin from the plant material into the bloodstream, as compared to the pure drug, had already been observed ${ }^{18}$.

Considering the potential usefulness of $A$. annиa $\mathrm{L}$. and its botanical products, in the present study, we assessed the in vitro and in vivo antileishmanial activity of the $A$. апnиa L. leaf powder in $L$. (V) panamensis. Furthermore, the potential usefulness of this herbal product was evaluated in $2 \mathrm{CL}$ patients with a short evolution history. To our knowledge, this is the first study to report the in vitro and in vivo activity of $A$. annua L. in $L$. (V) panamensis, and the potential usefulness of a herbal product comprising the entire leaves of $A$. аппиа $\mathrm{L}$. in the treatment of uncomplicated CL.

\section{METHODS}

\section{Artemisia annua $\mathrm{L}$. leaf powder}

Artemisia annua L. material was collected in WalferdangeLuxembourg in September 2012, from plants cultivated in the Colabor Garden. Certified organic material, including 1 specimen registered as MNHNL17732, was deposited in the Herbarium LUX, at the Musée National d'Histoire Naturelle, Luxembourg. The material was analyzed in the Laboratoire National de la Santé de Luxembourg, which is ISO 17025 certified. The leaves and thin branches were harvested, dried for 3 days at $35^{\circ} \mathrm{C}$, and pulverized to obtain a powder that was dispensed in gelatin capsules (Figure 1A). All the processes were conducted using Good Manufacturing Practice (Phytosanitary Certificate \# EC/LU/11773) at the semi-industrial facilities of Téi vum Séi in Winseler-Luxembourg.

For the in vitro assays, the powder of 3 capsules was solubilized in a phosphate-buffered saline (PBS) solution

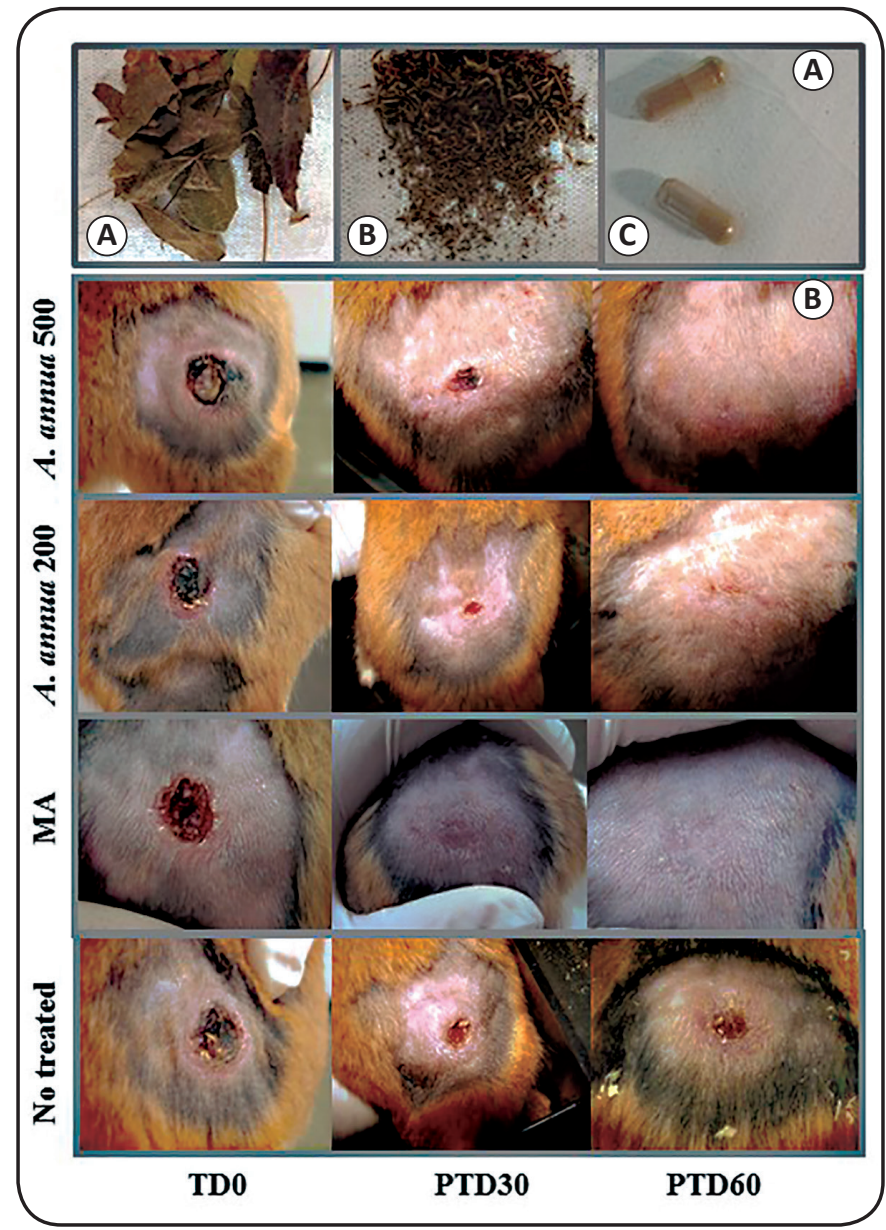

FIGURE 1 - Treatment with Artemisia annua L. leaf powder and the evolution of lesions in hamsters. In panel (A), the image shows the process of obtaining capsules from the leaves of Artemisia annua: the leaves and thin stems are selected from the whole plant (a), are pulverized (b), and are then powdered and packaged in gelatin capsules (c). In panel (B), the image shows the clinical appearance of the lesion in a representative hamster before (pre-treatment) and 30 and 60 days after treatment (PTD30 and PTD60, respectively) with 500 or $200 \mathrm{mg} / \mathrm{kg} /$ day (oral) of Artemisia annua L. leaf powder or meglumine antimoniate (intramuscular injection). MA: meglumine antimoniate; TD0: treatment day 0; PTD30: post-treatment day 30; PTD60: post-treatment day 60.

with $0.05 \%$ dimethyl sulfoxide (DMSO; Sigma); the concentration was adjusted to $200,100,50,25,12.5$, and $6.25 \mu \mathrm{L} / \mathrm{mL}$ in a complete medium containing Roswell Park Memorial Institute (RPMI-1640) medium (Sigma-Aldrich, St Louis MO, USA) supplemented with 10\% fetal bovine serum (FBS; Gibco, Life technologies Gaithersburg MD, USA) and a $1 \%$ penicillin $(10,000$ units $/ \mathrm{mL})$-streptomycin $(10 \mathrm{mg} / \mathrm{mL})$ solution (Sigma) to determine cytotoxicity or at $100,25,6.25$, and $1.56 \mu \mathrm{L} / \mathrm{mL}$ to determine antileishmanial activity.

For the in vivo assays, the powder of 10 capsules was solubilized in ultrapure water with $0.05 \%$ DMSO via sonication and homogenization.

\section{Cell line}

Human U-937 promonocytes (CRL1593.2 ${ }^{\mathrm{TM}}$, American Type Culture Collection Manassas, VA, USA) were cultured in standard conditions in complete RPMI-1640 medium and 
incubated at $37^{\circ} \mathrm{C}$ under $5 \% \mathrm{CO}_{2}$. The medium was changed every 3 days until use.

\section{Parasites}

Leishmania (Viannia) panamensis transfected with the green fluorescent protein (GFP), MHOM/CO/87/UA140-pIR-eGFP, were maintained as promastigotes via culture in a biphasic Novy-MacNeal-Nicolle (NNN) medium, and incubated at $26^{\circ} \mathrm{C}$.

\section{In vitro cytotoxicity assay}

The cytotoxicity of the A. annua L. leaf powder was determined in mammalian U-937 cells based on its effect on cell growth, as determined by the [3-(4,5-Dimethylthiazol-2yl)-2,5-Diphenyltetrazolium Bromide]-MTT microenzymatic assay described previously ${ }^{19}$.

\section{Genotoxicity test}

The effect of $A$. аппиа $\mathrm{L}$. powder on chromosome alteration was determined in vitro using the Organisation for Economic Co-operation and Development (OECD) guideline No. 473 chromosome aberration test ${ }^{20}$.

\section{In vitro antileishmanial activity of Artemisia annua capsules}

The antileishmanial activity was tested in intracellular amastigotes obtained after the infection of U937 cells with promastigotes of $L$. (V) panamensis UA140-pIR-eGFP, as described previously ${ }^{19}$.

\section{Leishmanicidal response in hamsters treated with Artemisia annua L. leaf powder}

The therapeutic response to $A$. annua L. leaf powder was evaluated in hamsters (Mesocricetus auratus) experimentally infected with $L$. (V) panamensis, as described previously ${ }^{21}$. Five experimental groups $(n=6$ each) consisting of males $(n=3)$ and females $(\mathrm{n}=3)$, were established. Two groups were treated with $100 \mu \mathrm{L}$ A. аппиа L. leaf powder at 500 and $200 \mathrm{mg} / \mathrm{kg} /$ day, which was administered orally, once daily, for 30 days. The third group was treated with $100 \mu \mathrm{L}$ MA at $120 \mathrm{mg} / \mathrm{kg} /$ day via an intramuscular injection, once daily, for 10 days. The fourth and fifth groups corresponded to non-infected hamsters and hamsters that were infected but not treated.

Treatments were initiated immediately after the development of a typical ulcer. The ulcer areas and body weight were measured at 2-week intervals from the start of treatments to the end of the study which occurred 2 months after completion of treatment. The overall time points of evaluation were as follows: pre-treatment day (TD0), end of treatment (TD14), and posttreatment days (PTD) 30 and 60.

At PTD60 (end of the study), hamsters were humanely sacrificed, and after necropsy, liver and kidney biopsies were conducted for histopathological studies, and sample of the ulcer was also used to determine the number of living $L$. $(V)$ panamensis parasites through the amplification of a single copy gene of Leishmania using quantitative reverse transcription polymerase chain reaction (qRT-PCR) ${ }^{22}$.
The effectiveness of each treatment was assessed by comparing the lesion sizes before and after treatments. The treatment outcome at the end of study was recorded as cured (healing of $100 \%$ of the ulcer area and complete disappearance of the lesion), improvement (reduction in the size of the lesion area by $>30 \%$ ), no response (increase in the size of the lesion area), or relapse (reactivation of the lesion after an initial cure). An arbitrary score of 3: cure, 2: improvement, 1: relapse, and 0: no response was assigned to each outcome in order to compare the effectiveness among the groups of treatments.

The toxicity of treatments was evaluated by comparing the blood levels of alanine amino transferase (ALT), blood urea nitrogen (BUN), and creatinine using commercially available kits (Biosystems, Spain), as described previously ${ }^{23}$. Blood samples were drawn from the heart on TD0 and TD8, and serum was stored at $-80^{\circ} \mathrm{C}$ until use.

\section{Case report of two patients with uncomplicated cutaneous leishmaniasis treated with Artemisia annua L. leaf powder}

The first patient (P01) was a 35-year-old man who presented in April 2014 with 4 ulcers with a 1-month evolution history, localized in the right ( 1 ulcer) and left ( 3 ulcers) legs, without any signs of over-infection. The sizes of the lesions (including ulcer plus induration) were $30 \mathrm{~mm} \times 28 \mathrm{~mm}, 10 \mathrm{~mm} \times 9 \mathrm{~mm}$, $45 \mathrm{~mm} \times 45 \mathrm{~mm}$, and $10 \mathrm{~mm} \times 10 \mathrm{~mm}$. The second patient $(\mathrm{P} 02)$ was a 28 -year-old man who presented in September 2014 with 1 ulcer on the right flank of the body $(50 \mathrm{~mm} \times 40 \mathrm{~mm}$, including ulcer plus induration) with a 6-week evolution history, without any apparent over-infection. In both patients, Giemsa-stained smears and culture aspirates in NNN medium indicated positive results for leishmaniasis. $L$. (V) panamensis was identified by PCR-RFLP (restriction fragment length polymorphism) using the methodology described previously ${ }^{24}$.

Both patients had not history of treatment with antileishmanial drugs. As both patients were in good clinical and physical condition, they were recommended to undergo treatment with A. anпиa $\mathrm{L}$. leaf powder. The patients signed the informed consent form and volunteered to receive the treatment. The patients were then treated with capsules containing $A$. аппи $\mathrm{L}$. leaf powder (total of $30 \mathrm{~g}$ over 20 days) as follows: $3 \mathrm{~g}$ (3 capsules) from treatment day (TD) one (TD1) to TD3; $2 \mathrm{~g}$ (2 capsules) from TD4 to TD7, and $1 \mathrm{~g}$ (1 capsule) from TD8 to TD20.

\section{Statistical analysis}

Cytotoxicity was determined based on the percentages of viability and cell growth inhibition, obtained for A. аппи $\mathrm{L}$. leaf powder, amphotericin B, or the cell culture medium using Eq.1:

$\%$ viability $=(O D$ of treated cells $) /(O D$ of control cells $) \times 100(1)$

where the OD of control cells corresponded to $100 \%$ viability.

Thereafter, the percentage of cell growth inhibition was estimated using Eq.2:

$\%$ cell growth inhibition $=100 \%$ viability $(2)$ 
The results are expressed as lethal concentration $50\left(\mathrm{LC}_{50}\right)$ and $90\left(\mathrm{LC}_{90}\right)$, which correspond to the concentration of A. annua $\mathrm{L}$. leaf powder that yielded $50 \%$ and $90 \%$ inhibition of cell growth. The $\mathrm{LC}_{50}$ and $\mathrm{LC}_{90}$ values were calculated using the Probit method ${ }^{25}$, and the degree of cytotoxicity of $A$. annua L. leaf powder was graded as follows $-\mathrm{LC}_{50}<100 \mu \mathrm{g} / \mathrm{mL}$ : high cytotoxicity, $\mathrm{LC}_{50} 100-200 \mu \mathrm{g} / \mathrm{mL}$ : moderate cytotoxicity, and $\mathrm{LC}_{50}>200 \mu \mathrm{g} / \mathrm{mL}$ : potential non-cytotoxicity.

The in vitro antileishmanial activity of $A$. annua $\mathrm{L}$. leaf powder in intracellular amastigotes was determined according to the percentage of infected cells corresponding to the number of positive events based on green fluorescence imaging and forward scatter by dotplot analysis, and the median fluorescence intensity by histograms. Both parameters were used to calculate the percentage of infection for each concentration using Eq.3:

$\%$ infection $=(\%$ infected, treated cells $\div \%$ infected, untreated cells $) \times 100(3)$

Thereafter, the percentage of infection inhibition was calculated using equation 4 :

$$
\% \text { Inhibition = } 100-\% \text { infection(4) }
$$

The results of activity are expressed as effective concentration $50\left(\mathrm{EC}_{50}\right)$ and effective concentration $90\left(\mathrm{EC}_{90}\right)$, which correspond to the concentration of $A$. апnиa $\mathrm{L}$. leaf powder that yielded $50 \%$ and $90 \%$ of inhibition of the parasitic infection, respectively. The $\mathrm{EC}_{50}$ and $\mathrm{EC}_{90}$ were determined using Probit analysis ${ }^{25}$. The degree of antileishmanial activity was established based on the $\mathrm{EC}_{50}$ values, as follows $-\mathrm{EC}_{50}<25 \mu \mathrm{g} / \mathrm{mL}$ : antileishmanial activity, $\mathrm{EC}_{50} 25-50 \mu \mathrm{g} / \mathrm{mL}$ : moderate activity, and $\mathrm{EC}_{50}>50 \mu \mathrm{g} / \mathrm{mL}$ : non-antileishmanial activity. Moreover, the Index of Selectivity (IS) was calculated by dividing the cytotoxicity and the antileishmanial activity using Eq.5:

$$
\mathrm{SI}=\mathrm{CL} 50 / \mathrm{CE} 50(5) \text {. }
$$

For statistical analysis of in vivo data, a one-way analysis of variance and Kruskal-Wallis test, followed by the postcontrast Dunn's Multiple Comparison Test, was performed using GraphPad Prism 6 software (GraphPad Software, Inc., San Diego, CA, USA). A $p$ value of $<0.05$ was considered to be statistically significant.

\section{Ethical considerations}

The Institutional Ethics Committee for Human Research of CES University approved the protocol in human patients (Act No. 66-2014), and informed consent was obtained from all the participants in the study. This work was also approved by the Ethics Committee for Animal Research of the University of Antioquia (Act No. 72-2011 and 91-2014).

\section{RESULTS}

\section{In vitro toxicity of Artemisia annua $\mathrm{L}$. leaf powder}

The in vitro cytotoxic effect of this herbal product was assessed in human macrophages (U-937), and we found that A. annua $\mathrm{L}$. leaf powder was non-cytotoxic to $\mathrm{U}-937$, as evidenced by an $\mathrm{LC}_{50}$ of $419.1 \mu \mathrm{g} / \mathrm{mL}$. In contrast, amphotericin B was cytotoxic to U-937 cells $\left(\mathrm{LC}_{50}, 30 \mu \mathrm{g} / \mathrm{mL}\right)$.

In the chromosome aberration test, human lymphocytes treated with $A$. annua L. leaf powder did not exhibit chromosomal aberrations at any of the concentrations tested, compared to that noted with the negative control (Table 1). No statistically significant differences between the negative control and $A$. аппиа $\mathrm{L}$. leaf powder-treated groups were observed $(p=0.527)$.

\section{In vitro antileishmanial activity of Artemisia annua L. leaf powder}

The in vitro antileishmanial activity of $A$. annua $\mathrm{L}$. leaf powder was assessed in U-937 macrophages that were infected with amastigotes of $L$. (V) panamensis. The product showed moderate leishmanicidal activity on the intracellular amastigotes of $L$. (V) panamensis, with $\mathrm{EC}_{50}$ and $\mathrm{EC}_{90}$ values of $48.07 \mu \mathrm{g} /$ $\mathrm{mL}$ and $82.2 \mu \mathrm{g} / \mathrm{mL}$, respectively. As expected, amphotericin B

TABLE 1

Percentage of chromosome breaks observed in human lymphocytes exposed to various compounds with leishmanicidal potential for

\begin{tabular}{|c|c|c|c|c|c|c|c|c|c|}
\hline \multirow[b]{2}{*}{ Compound } & \multirow[b]{2}{*}{$\mu \mathrm{g} / \mathrm{mL}$} & \multicolumn{2}{|c|}{ B } & \multicolumn{2}{|c|}{ BB } & \multicolumn{2}{|c|}{ MR } & \multicolumn{2}{|c|}{ DC/R } \\
\hline & & $\mathbf{n}$ & $\%$ & $\mathbf{n}$ & $\%$ & $\mathbf{n}$ & $\%$ & $\mathbf{n}$ & $\%$ \\
\hline $\mathrm{C}-$ & 0 & 2 & 0.8 & 0 & 0.0 & 0 & 0.0 & 0 & 0.0 \\
\hline \multirow[t]{2}{*}{ Artemisia annua } & 25 & 4 & 2.7 & 0 & 0.0 & 1 & 0.7 & 0 & 0.0 \\
\hline & 100 & 6 & 2.4 & 4 & 1.6 & 0 & 0.0 & 0 & 0.0 \\
\hline
\end{tabular}
24 hours.

B: chromatid breaks; BB: chromosome break; DC: dicentric chromosomes; R: ring chromosomes, MR: multiradial chromosomes; C-: negative control.. $p>0.5$, in comparison with the untreated group (Bonferroni test). 
was highly active against the intracellular amastigotes of $L$. $(V)$ panamensis, with $\mathrm{EC}_{50}$ and $\mathrm{EC}_{90}$ values of $0.06 \mu \mathrm{g} / \mathrm{mL}$ and $0.1 \mu \mathrm{g} /$ $\mathrm{mL}$, respectively. Moreover, the biological activity of $A$. аппиа L. leaf powder was more selective for parasites than for cells, with an IS of 8.73; in contrast, the IS of amphotericin B was 625.

Therapeutic response and toxicity of Artemisia annua L. leaf powder in hamsters with experimental cutaneous leishmaniasis

The effectiveness of $A$. апnиа $\mathrm{L}$. leaf powder was determined in hamsters based on the evolution of the lesions after treatment, in comparison with treatment with MA or no treatment, wherein cure was defined as the resolution of the infection with complete skin re-epithelialization (Figure 1B). The treatment of hamsters with CL caused by $L$. (V) panamensis with $A$. апnиa L. leaf powder at $500 \mathrm{mg} / \mathrm{kg} /$ day for 30 days resulted in cure in 5 up 6 hamsters ( 3 males and 2 females; $83.3 \%$ ) at the end of the study period (PTD60; Figure 2A). Notably, cure was observed in some hamsters early after treatment, and the number of those cured increased over time. Thus, at the end of the treatment period, 2 up 6 hamsters were cured, whereas at PT30, 4 up 6 hamsters $(66.6 \%)$ were cured. The parasitic load in the hamster that was not cured was 188,47 parasites per mg of tissue. In contrast, treatment with $A$. аппиа $\mathrm{L}$. leaf powder, at a dose of $200 \mathrm{mg} /$ $\mathrm{kg} /$ day for 30 days, led to cure in 2 up 6 hamsters ( 1 male and 1 female) at the end of the treatment period; however, at PTD30, both these animals experienced a relapse. At the end of the study (PTD60), improvement in lesion size, treatment failure, and relapse were each observed in $33.3 \%$ cases (Figure 2A). The parasitic load in this group of hamsters at the end of the study was $272.15 \pm 164.4$ parasites/mg tissue. MA treatment was found to have cured all the animals of this group at the end of the study, and no live parasites were detected in any of these animals. In contrast, none of the hamsters in the non-treated group were cured during the study period (Figure 2A). Three hamsters showed a reduction in their lesion size during the first month after infection, although they experienced a relapse subsequently; thus, all the hamsters had larger lesions at the end of the study period as compared to those at baseline. The parasitic load in this group was $541.456 .8 \pm 490.728 .0$ parasites $/ \mathrm{mg}$ of tissue. In the present study, no differences in the response to treatment (either A. annиa or MA) and the sex of the animal were observed.

At the end of the study, the effectiveness of oral treatment with $A$. аппиа L. leaf powder, administered at $500 \mathrm{mg} / \mathrm{kg} / \mathrm{day}$ for 30 days, was similar to that observed with the intramuscular injection of MA, in terms of the clinical outcome and parasite load, at the end of the study $(p>0.05)$. However, the effectiveness of the treatment was different when A. апnи $\mathrm{L}$. leaf powder was administered at a dose of $200 \mathrm{mg} / \mathrm{kg}(p<0.05)$.

None of the animals in the treatment groups experienced weight loss (Figure 2B). In contrast, weight gain was observed in all the hamsters during the study, which suggests that no toxic effect was produced in hamsters due to treatment with $A$. аппиа $\mathrm{L}$. leaf powder.

The serum values of ALT, BUN, and creatinine were measured on TD8 and PTD45 to determine whether the oral administration of $A$. апnиa $\mathrm{L}$. leaf powder led to hepatic or renal dysfunction. We found that the levels of BUN and ALT in both groups of hamsters treated with $A$. аппи $\mathrm{L}$. leaf powder (200 or $500 \mathrm{mg} / \mathrm{kg} / \mathrm{day}$ ) were similar to the levels of hamsters that were not infected or infected and untreated, without any

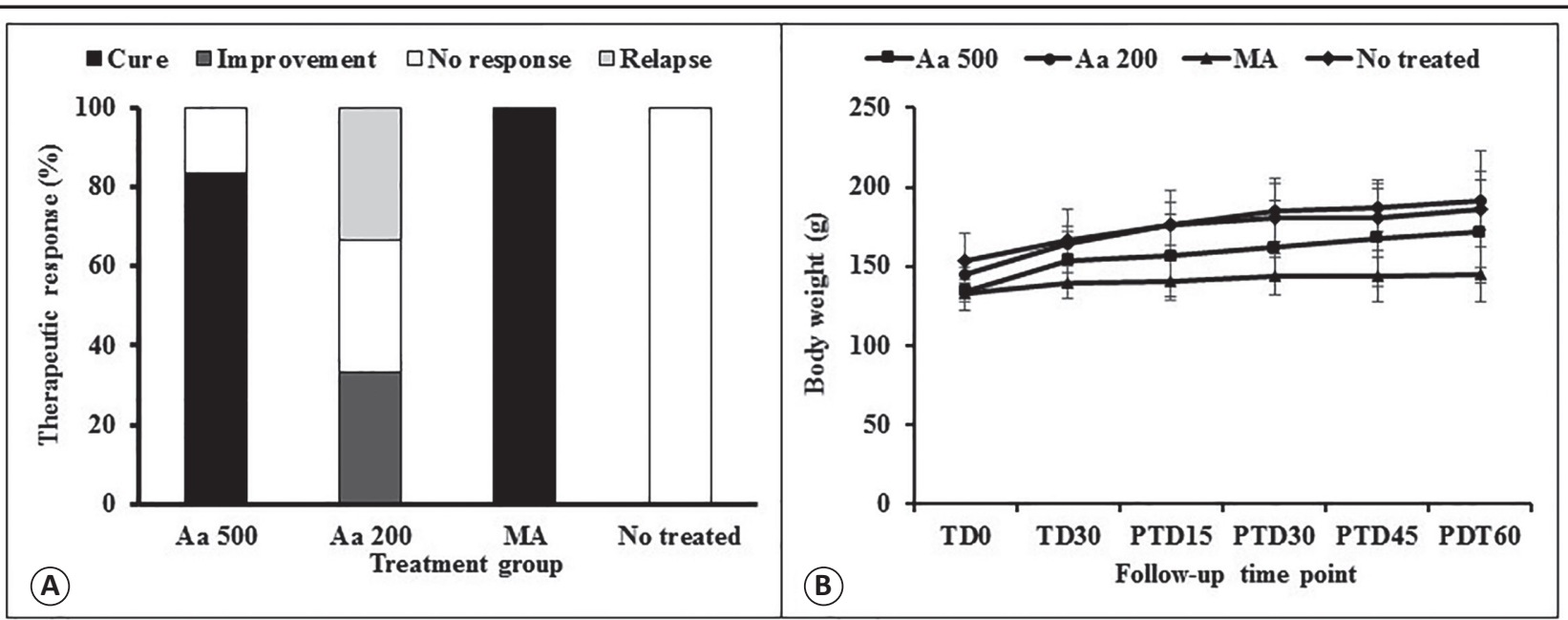

FIGURE 2 - In vivo therapeutic response and effect on body weight in hamsters with cutaneous leishmaniasis treated with Artemisia annua L. leaf powder. The treatment outcome was evaluated at the end of treatment period (PTD60) in hamsters treated with Artemisia annua L. leaf powder at dose of 500 or $200 \mathrm{mg} / \mathrm{kg} / \mathrm{day}$ (oral) versus meglumine antimoniate (intramuscular injection) versus no treatment. In (A), the bars represent the percentage of animals showing cure, improvement, failure, or relapse findings after 60 days of treatment. The differences between the groups were not significant $(p=0.3679)$. In (B), the lines represent the evolution of body weight in grams in hamsters orally treated with $500 \mathrm{or} 200 \mathrm{mg} / \mathrm{kg} /$ day of Artemisia annua L. leaf powder, in those treated intramuscularly with meglumine antimoniate (MA) at $120 \mathrm{mg} / \mathrm{kg} / \mathrm{day}$, and in those without any treatment. The differences between the groups were not significant ( $p>0.05)$. Aa 500: A. аппиа 500mg/kg/d; Aa 200: A. аппиа 200mg/kg/d; MA: meglumine antimoniate; TD0: treatment day 0; TD30: treatment day 30; PTD15: post-treatment day 15; PTD30: post-treatment day 30; PTD45: post-treatment day 45; PTD60: post-treatment day 60. 
significant differences ( $p=0.9988$; Figure 3). In contrast, the treatment with MA increased the ALT levels at TD8 and PTD45, in comparison with those observed in the other treatment groups; this difference was significant $(p<0.0001)$.

Histopathological analyses of the kidney indicated mild vacuolar degeneration, atrophy, hyperplasia, protein cylinders, and congestion in 1-2 animals in each treatment group, including the non-treated controls. Similarly, cloudy and vacuolar degeneration, karyomegaly, binucleation, and congestion were observed in the liver of few animals in each treatment group. As the histological changes were also observed in the non-treated animals, these alterations can be considered to be associated with the parasitic infection rather than the treatment.

Response to Artemisia annua L. leaf powder in two patients with uncomplicated cutaneous leishmaniasis treated with

Patients treated with a total of $30 \mathrm{~g}$ of $A$. annua L. leaf powder for 20 days responded very well. At the end of treatment (TD21), the ulcers decreased in size by approximately $20-35 \%$, as compared to that before treatment. In both patients, complete cure $(100 \%$ closure of the ulcer and presence of scar in the lesion site) was observed on day 45 after the end of treatment (PTD45); however, no good resolution images that indicated the cure could be obtained. The patients remained disease-free after 2 years of follow-up. Figure 4A shows the appearance of 2 lesions in patient P01 at TD0 (a), TD20 (b), and 12 months after the end of treatment (c). Similarly, Figure 4B shows the appearance of the ulcer in patient P02 at TD0 (a), TD10 (b), and 12 months after the end of treatment. Both patients remained disease-free at 26 and 24 months after treatment completion. Moreover, both patients did not develop any side-effects or adverse reactions. In the first patient, only the amylase level was mildly elevated before, during, and after treatment (133, 156 , and $144 \mathrm{U} / \mathrm{L}$ on day 0 and 10 of treatment and day 45 posttreatment, respectively). The drug showed no impact on body function. The increased amylase levels prior to treatment did not affect patient management, but appears to be an incidental finding that did not interfere with the treatment.

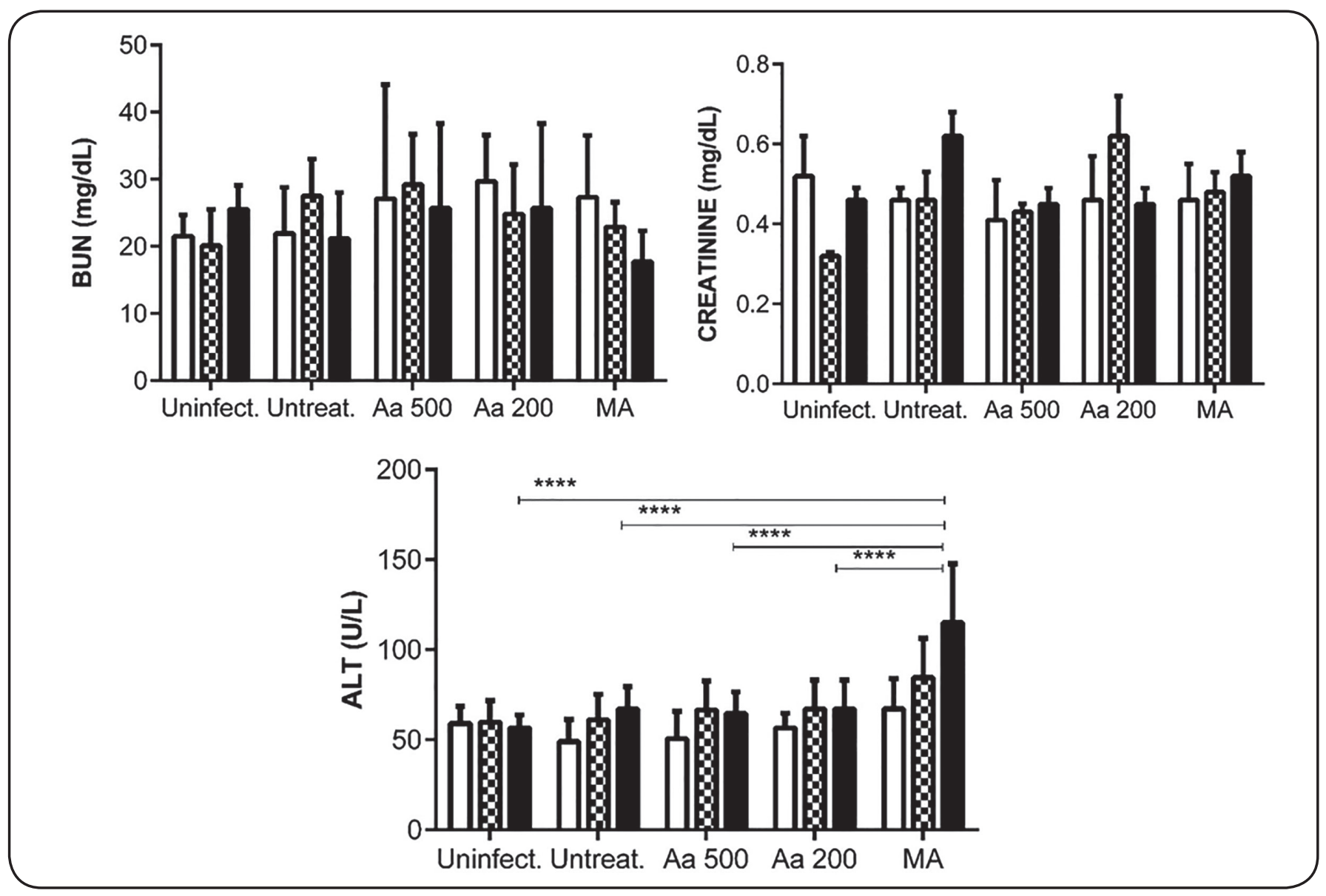

FIGURE 3 - Serum levels of BUN, creatinine, and ALT in hamsters before and after treatment with Artemisia annua L. leaf powder. Golden hamsters ( $\mathrm{n}=6$ per group) were orally treated for 30 days with $A$. annua L. leaf powder at $500 \mathrm{mg} / \mathrm{kg} / \mathrm{day}$ or $200 \mathrm{mg} / \mathrm{kg} / \mathrm{day}$. A third group of hamsters was intramuscularly treated for 10 days with meglumine antimoniate at $120 \mathrm{mg} / \mathrm{kg} /$ day. Two additional groups of hamsters were included as controls: uninfected hamsters and hamsters that were infected but not treated. The bars represent the mean value of the corresponding metabolite detected before (white bar), on treatment day 8 (black and white squares bar), and on day 45 after treatment (black bar). The differences in the serum level of ALT of hamsters treated with MA were significant between the groups $(p<0.0001)$. Data represent the median values \pm SD of 6 animals per treatment group. Aa 500: A. annиa 500mg $/ \mathrm{kg} / \mathrm{d} ; \mathbf{A a}$ 200: A. annua 200mg/kg/d; MA: meglumine antimoniate; BUN: blood urea nitrogen; ALT: alanine amino transferase; SD: standard deviation. ${ }^{* * * *} \mathrm{p}<0.0001$ 


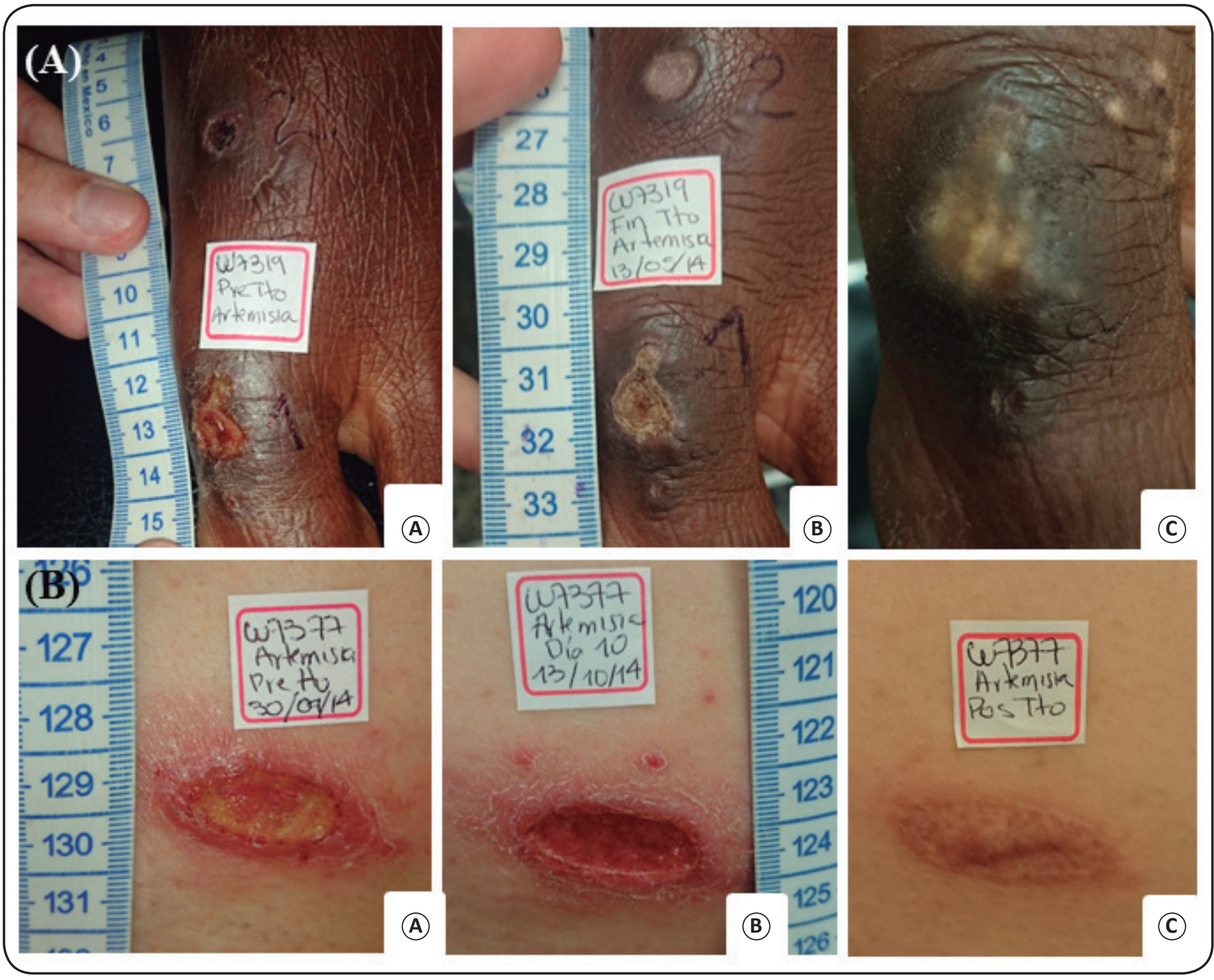

FIGURE 4. Lesion evolution in patients after treatment with Artemisia annua L. leaf powder. The Figure shows the evolution of lesions in patient $\mathrm{P} 01$ (panel A) and P02 (Panel B at TD0 (before treatment) (a), TD10 (b), and 12 months after treatment completion (c). This patient had 4 ulcers. All the ulcers were cured at day 45 after treatment with a total of 30g of Artemisia апnиa L. leaf powder; patient P01 and P02 remained disease-free over 26 and 24 months of follow-up, respectively. No relapses were observed during this time. P01: patient 01; P02: patient 02; TD0: treatment day 0; TD10: treatment day 10.

\section{DISCUSSION}

CL is an infectious disease that can lead to serious psychological and social stigma, particularly in cases where the face and other visible areas are affected. Thousands of plants, have been used as medicines for several human diseases. Over the last decade, the development of drugs from medicinal herbs and phytochemicals from plants has been receiving increased attention through standardized and systematic research. Hence, currently, medicinal herbs and their derivative phytocompounds are being increasingly used as primary or complementary treatments for several diseases, including cancer. In particular, A. annua L. has been used for more than 2000 years in Chinese traditional herbal medicine for the treatment of fever, without any apparent emergence of resistance to artemisinin.

In the present study, the effectiveness and safety profile of A. annua L. leaf powder was found to be highly satisfactory.
A. аnпиа L. leaf powder showed in vitro antileishmanial activity with no evidence of cytotoxicity or genotoxicity. As genotoxicity analyses based on only chromosomal aberration studies and with low compound concentrations are not sufficiently sensitive to detect genotoxicity and mutagenicity, others tests such as Comet, Ames, and Vitotox tests, which would be more sensitive, should be performed to identify significant dose-dependent genotoxicity and mutagenicity of $A$. annua L. Although the IS of amphotericin B was higher than that of $A$. annua L. leaves powder, a value of 8 is considered important to identify a compound as promising to continue the evaluation phases in drug discovery and development.

On the other hand, no detrimental effect on body weight or blood levels of ALT, BUN, and creatinine were observed in hamsters after treatment. The BUN, creatinine, and ALT 
levels were not only slightly increased in hamsters treated with A. аппиа $\mathrm{L}$. leaf powder and MA, but also in infected and nontreated hamsters. These results suggest that such an increase may probably be associated with the infection process of $L$. $(V)$ panamensis. In addition, the ability of $A$. апnи $\mathrm{L}$. leaf powder to kill the intracellular amastigotes of $L$. (V) panamensis present in the ulcer, and cure cutaneous leishmaniasis was demonstrated in hamsters; nevertheless, the efficacy may be affected by the dose, since the same product administered at a dose of $200 \mathrm{mg} /$ $\mathrm{kg}$ body weight/day for 30 days produced a cure, but at a very low rate and with relapse during the follow-up period.

Various products derived from $A$. аппиа $\mathrm{L}$. have been reported to have activity against Leishmania species. For example, the $\mathrm{n}$-hexane extracts of $A$. апnи $\mathrm{L}$. leaves and seeds induce apoptosis in intracellular amastigotes of $L$. (L) donovani without any cytotoxic effects on mammalian macrophages and the treatment of infected mice with these n-hexane extracts significantly decreased the hepatic and splenic parasitic load, and reduced spleen weight ${ }^{15}$. In another study, the essential oils of $A$. аnnиa L. leaves exhibited significant in vitro leishmanicidal activity against intracellular amastigotes of $L$. (L) donovani, without any cytotoxicity on murine macrophages, and the intra-peritoneal administration $(200 \mathrm{mg} /$ $\mathrm{kg}$ body weight) to infected BALB/c mice reduced the parasitic burden by almost $90 \%$ in the liver and spleen and significantly reduced the weight of these organs as well. No hepato- or nephrotoxicity was observed in these cases, as evidenced by the normal levels of the serum enzymes ${ }^{16}$. However, complete cure of VL with $A$. аnnua n-hexane extracts nor essential oils has not been observed in these in vivo studies.

Finally, we assessed the potential usefulness of $A$. annua $\mathrm{L}$. leaf powder to treat $\mathrm{CL}$ with a short evolution history, at a low dose. Rapid evolution of the lesion with complete healing was observed 1.5 months after treatment with $A$. апnи $\mathrm{L}$. leaf powder. Although the spontaneous healing of lesions caused by $L$. (V) panamensis has been reported in CL, this phenomenon usually occurs after several months of evolution and not during the initial stages.

These results are consistent with previous studies, wherein the efficacy of the whole plant of $A$. апnи $\mathrm{L}$. was demonstrated. The use of the whole plant was found to be more effective in the treatment of a rodent malaria model, as compared to the use of a comparable dose of pure artemisinin ${ }^{26}$. Moreover, the consumption of $A$. аппиа $\mathrm{L}$. tea once a week over long periods ( $2.6 \pm 1.4$ years) by farm workers in Africa was found to significantly reduce the episodes of malaria, in comparison with workers who did not drink the tea; no adverse effects of such tea consumption on the health of workers was observed ${ }^{27} 28$.

The content of artemisinin in the capsules containing $A$. annua $\mathrm{L}$. leaf powder is approximately $0.1 \%$; hence, it can be estimated that $1-3 \mathrm{mg}$ of artemisinin was administered daily. As the capsules only contain leaves, the possibility of the sub-therapeutic doses to generate resistance in malaria is low $^{29}$. The advantage of $A$. апnиа $\mathrm{L}$. powder, in comparison to the tea preparation, is that the powder may supply all the molecules present in the plant, particularly the polysaccharides, coumarins, saponins, phytosterols, essential oils, polyphenols, and flavonoids ${ }^{30}$. These molecules were reported to enhance the action of artemisinin ${ }^{31}$ and may also have their own specific antimalarial action ${ }^{32}$.

The consumption of tea infusion and dried leaves of the plant may have prophylactic and therapeutic efficacy, due to the presence of a complex matrix of chemicals within the leaves, which appears to enhance both the bioavailability and efficacy of artemisinin. Rodent studiesindicated longer pharmacokinetic parameters in Plasmodium chabaudi-infected mice treated with $A$. аnпиa dried leaves as compared to those in healthy mice. In healthy mice, the serum levels of artemisinin were $>40$-fold greater among those fed with dried leaves as compared to those fed with pure artemisinin. Human trial data also showed that when artemisinin was delivered in the form of dried leaves, 40-fold less artemisinin was required to obtain a therapeutic response, as compared to when pure artemisinin was administered ${ }^{33}$. However, future studies need to assess whether an increase in the dose will enhance the efficacy.

In conclusion, to our knowledge, this is the first study to describe the therapeutic response of CL patients to A. аnnиa L. leaf powder, and to report the in vitro and in vivo activity of this compound against $L$. (V) panamensis. Overall, the bioassay testing results showed that the administration of $A$. аппиа L. leaf powder is easy and apparently safer and more effective than consumption as tea or pure drug infusion, and hence, it may serve as an adequate option for the treatment of non-complicated CL. Although these findings need to be confirmed, we observed that the therapeutic response to this herbal product might be enhanced by increasing the dose or frequency of administration. The potential effectiveness and safety of $A$. annua $\mathrm{L}$. leaf powder observed in the present study could serve as fundamental evidence for considering this herb product as an alternative for CL treatment, and presents opportunities for future explorations of herb formulations in the treatment of CL.Moreover, further investigations of the utility of $A$. annua L. totum in the treatment of $\mathrm{CL}$ is consistent with the strategy defined by the WHO to use and apply traditional medicine and its products over the next decade.

\section{Conflict of interest}

The authors declare no conflict of interest.

\section{Acknowledgements}

The authors thank the patients for agreeing to participate in the study.

\section{Financial support}

Departamento Administrativo de Ciencia, Tecnología e InnovaciónCOLCIENCIAS (project number CT-695-2014) and University of Antioquia (Centros de Excelencia).

\section{REFERENCES}

1. World Health Organization WHO. Control of the leishmaniasis: report of a meeting of the WHO Expert Committee on the Control of Leishmaniases. World Health Organization Tech Rep Ser 2010;949:1-186. 
2. Alvar J, Velez ID, Bern C, Herrero M, Desjeux P, Cano J. Leishmaniasis Worldwide and Global Estimates of Its Incidence. PloS One. 2012;7(5):e35671.

3. den Boer M, Argaw D, Jannin J, Alvar J. Leishmaniasis impact and treatment access. Clin Microbiol Infect. 2011; 17(10):1471-7.

4. Mishra BB, Tiwari VK. Natural products: an evolving role in future drug discovery. Eur J Med Chem. 2011;46(10):4769-807.

5. World Health Organization WHO traditional medicine strategy: 2014-2023. Geneva, 2014. http://www.who.int/medicines/ publications/traditional/trm_strategy14_23

6. Klayman DL. Qinghaosu (artemisinin): an antimalarial drug from China. Science. 1985;228(4703):1049-55.

7. Hsu E. The history of qing hao in the Chinese materia medica. Trans R Soc Trop Med Hyg. 2006;100(6):505-8.

8. Efferth T, Herrmann F, Tahrani A, Wink M. Cytotoxic activity of secondary metabolites derived from Artemisia annua L. towards cancer cells in comparison to its designed active constituent artemisinin. Phytomed. 2011;18(11):959-69.

9. Helal EGE, Abou-Aouf N, Khattab AM, Zoair MA. Anti-diabetic effect of Artemisia annua (kaysom) in alloxan-induced diabetic rats. Egyp J Hosp Med. 2014;57:422-30. doi:10.12816/0008476.

10. Efferth T, Romero M, Wolf D, Stamminger T, Marin J, Marschall M. The antiviral activities of artemisinin and artesunate. Clin Infect Dis. 2008;47(6):804-11.

11. Lubbe A, Seibert I, Klimkait T, van der Kooy F. Ethnopharmacology in overdrive: The remarkable anti-HIV activity of Artemisia annua. J Ethnopharm. 2012;141(3):854-59.

12. Mishina YV, Krishna S, Haynes RK, Meade JC. Artemisinins inhibit Trypanosoma cruzi and Trypanosoma brucei rhodesiense in vitro growth. Antimicrob Agents Chemother. 2007;51(5):1852-4.

13. Sen R, Bandyopadhyay S, Dutta A, Mandal G, Ganguly S, Saha P, et al. Artemisinin triggers induction of cell-cycle arrest and apoptosis in Leishmania donovani promastigotes. J Med Microbiol. 2007;56(9):1213-8.

14. Yang D, Liew F. Effects of qinghaosu (artemisinin) and its derivatives on experimental cutaneous leishmaniasis. Parasitol. 1993;106(1):7-11

15. Islamuddin M, Farooque A, Dwarakanath BS, Sahal D, Afrin F. Extracts of Artemisia annua leaves and seeds mediate programmed cell death in Leishmania donovani. J Med Microbiol. 2012;61(12):1709-18.

16. Islamuddin M, Chouhan G, Tyagi M, Abdin MZ, Sahal D, Afrin F. Leishmanicidal activities of Artemisia annua leaf essential oil against visceral leishmaniasis. Front Microbiol. 2014;5:626. doi: 10.3389/fmicb.2014.00626.

17. Onimus M, Carteron S, Lutgen P. The Surprising Efficiency of Artemisia annua powder capsules. Med Arom Plants. 2013;2:125. doi:10.4172/2167-0412.1000125.

18. Weathers PJ, Arsenault PR, Covello P, McMickle A, Reed D, Teoh KH. Artemisinin production in Artemisia annиa - studies in plant and a novel delivery method for treating malaria and other neglected diseases. Phytochem Rev 2011;10(2):173-83.

19. Mesa CV, Blandón GA, Muñoz DL, Muskus CE, Flórez AF, Ochoa $\mathrm{R}$, et al. In silico screening of potential drug with antileishmanial activity and validation of their activity by in vitro and in vivo studies. J Chem Chem Eng. 2015;9:375-402. doi:10.17265/19347375/2015.06.002.

20. Organisation for Economic Co-operation and Development (OECD). Test No. 473: In Vitro Mammalian Chromosomal Aberration Test, OECD Guidelines for the Testing of Chemicals, Section 4, OECD Publishing, Paris. 2014

21. Robledo SM, Carrillo LM, Daza A, Restrepo AM, Muñoz DL, Tobón $\mathrm{J}$, et al. Cutaneous leishmaniasis in the dorsal skin of hamsters: a useful model for the screening of anti-leishmanial drugs. J Vis Exp. 2012;62:3533. doi: 10.3791/3533.

22. Carrillo LM, Montoya EA, Arbeláez N, Cadena H, Ramírez J, Robledo SM. Migration of Leishmania (Viannia) panamensis and its persistence in healthy skin of hamster. Rev UDCA Act Div Cient. 2014;17(2):341-50

23. Reynolds KM. The Kodak Ektachem dry layer technology for clinical chemistry. Upsala J Med Sci. 1986;91(2):143-6.

24. Montalvo AM, Fraga J, Rodríguez O, Blanco O, Llanos-Cuentas A, García AL, et al. Detection of Leishmania spp. based on the gene encoding HSP20. Rev Per Med Exp Salud Publica. 2014;31(4):63543.

25. Finney JD. Statistical Method in Biological Assay. $3^{\text {rd }}$ ed. London: Charles Griffin \& Co. Ltd, 1978; p. 508.

26. Elfawal MA, Towler MJ, Reich NG, Golenbock D, Weathers PJ, Rich SM. Dried whole plant Artemisia annua as an antimalarial therapy. PLoS One. 2012;7(12):e52746.

27. Ogwang PE, Ogwal JO, Kasasa S, Olila D, Ejobi F, Kabasa D, et al. Use of Artemisia annua L. infusion for malaria prevention: mode of action and benefits in a Ugandan community. Br J Pharm Res. 2011;1(4):124-32.

28. Ogwang PE, Ogwal JO, Kasasa S, Olila D, Ejobi F, Kabasa D, et al. Artemisia annua L. infusion consumed once a week reduces risk of multiple episodes of malaria: a randomised trial in a Ugandan community. Trop J Pharm Res. 2012;11(3):445-53.

29. Elfawal MA, Towler MJ, Reich NG, Weathers PJ, Rich SM. Dried whole-plant Artemisia апnиа slows evolution of malaria drug resistance and overcomes resistance to artemisinin. Proc Nat Acad Sci. 2015;112(3):821-6.

30. Bilia AR, Santomauro F, Sacco C, Bergonzi MC, Donato R. Essential Oil of Artemisia annua L.: an extraordinary component with numerous antimicrobial properties. Evid Based Complement Alternat Med 2014; 2014(1):159819. doi: 10.1155/2014/159819.

31. Ferreira JF, Luthria DL, Sasaki T, Heyerick A. Flavonoids from Artemisia annua L. as antioxidants and their potential synergism with artemisinin against malaria and cancer. Molecules. 2010;15(3):3135-70

32. Goulart HR, Kimura EA, Peres VJ, Couto AS, Aquino-Duarte FA, Katzin AM. Terpenes Arrest Parasite Development and Inhibit Biosynthesis of Isoprenoids in Plasmodium falciparum. Antimicrob Agents Chemother. 2004;48(7):2502-9.

33. Weathers PJ, Towler M, Hassanali A, Lutgen P, Engeu PO. Driedleaf Artemisia annua: A practical malaria therapeutic for developing countries? World J Pharmacol. 2014;3(4):39-55. 